\title{
REVIEWS
}

\section{PUBLIC AND COMMON GOODS IN THE CULTURAL LANDSCAPE}

\author{
AUTHORS \\ dr. Mateja Šmid Hribar \\ Research Centre of the Slovenian Academy of Sciences and Arts, Anton Melik Geographical Institute, Gosposka \\ ulica 13, SI - 1000 Ljubljana, Slovenia \\ mateja.smid@zrc-sazu.si
}

\section{dr. David Bole}

Research Centre of the Slovenian Academy of Sciences and Arts, Anton Melik Geographical Institute, Gosposka ulica 13, SI - 1000 Ljubljana, Slovenia

david.bole@zrc-sazu.si

\section{dr. Mimi Urbanc}

Research Centre of the Slovenian Academy of Sciences and Arts, Anton Melik Geographical Institute, Gosposka ulica 13, SI - 1000 Ljubljana, Slovenia

mimi.urbanc@zrc-sazu.si

DOI: $10.3986 / G V 87203$

UDC: $911.53: 332.33(497.4)$

COBISS: 1.02

\section{ABSTRACT}

\section{Public and common goods in the cultural landscape}

The main purpose of this paper is to review the literature and national documents, and define the meaning and roles of various types of good in the rural cultural landscape. We identified four main categories: private good, toll good, common good, and public good. The scope, uses, and benefits of goods in the cultural landscape change over time due to, inter alia, socio-political processes and formal (non)recognition at the institutional level. Further, we discuss how public good and common good benefit the community, and the necessity of sound management and conservation of common good in the form of common property. In the context of public good, supporting, regulating, and cultural ecosystem services are becoming increasingly important. They are non-subtractable, but they are inextricably linked to private land. As there are many points of conflict in the use of common and public goods, their protection should be provided in the relevant legislation.

\section{KEY WORDS}

geography, cultural landscape, public good, common good, ecosystem services, Slovenia

\section{IZVLEČEK}

\section{Javno in skupno dobro $v$ kulturni pokrajini}

Glavni namen prispevka je pregled strokovne literature in državnih dokumentov ter opredelitev pomena in vloge različnih tipov dobrega v podeželski kulturni pokrajini. Prepoznali smo štiri glavne kategorije: zasebno, plačljivo, skupno in javno dobro. Obseg, način rabe in koristi dobrega se v kulturni pokrajini spreminjajo skozi čas, tudi zaradi družbeno-političnih procesov in formalnega (ne)prepoznanja na institucionalni 
Mateja Šmid Hribar, David Bole, Mimi Urbanc $\quad$ Public and common goods in the cultural landscape

ravni. Poleg tega razpravljamo, kako javno in skupno dobro prinašata skupnosti koristi ter o nujnosti premišljenega upravljanja in ohranitvi skupnega dobrega. V kontekstu javnega dobrega so podporne, uravnalne in kulturne ekosistemske storitve vse pomembnejše. Z rabo sicer ne upadajo, a so neločljivo povezane $z$ zasebnimi zemljišči. Ker obstajajo mnoge točke konflikta v rabi skupnega in javnega dobrega, je njegova zaščita pomembna tudi na zakonodajni ravni.

KLJUČNE BESEDE

geografija, kulturna pokrajina, javno dobro, skupno dobro, ekosistemske storitve, Slovenija

The article was submitted for publication on June 19, 2015. 


\section{Introduction}

The cultural landscape is a good composed of tangible and intangible elements, formed in the several-hundred years of interactions between nature and man (Urbanc 2002; 2008; 2011). It is subject to constant change, partially due to natural factors, but mostly due to those of human lifestyle (Terkenli 2001; Buchecker, Hunziker and Kienast 2003).

Moreover, the landscape is a good at various levels and for various groups of people. Landowners are particularly interested in the economic value of the fully tangible elements of the landscape, but their management strategies also include intangible elements, such as tradition, memory, etc. On the other hand, people without economic interests (might) understand it completely differently, e.g. in the light of public good, but their decision-making clout may be limited. One of the oldest forms of common good is common land and related communities, rules, and traditional knowledge (Vilfan 1996; Petek and Urbanc 2007; Bogataj 2012; Rodela 2012a; Johann 2013; Olwig 2013), which in the past were exposed to various pressures - due to either economic, political, or ideological reasons (Vilfan 1957; 1972; Britovšek 1964; Gatto and Bogataj 2015). Their scope has decreased in recent decades due to socio-economic reasons (Petek and Urbanc 2007). Besides, common property and common good in Slovenia, unlike in some European countries (Gatto et al. 2011; Jenko 2012), are not formally recognised as a specific type of property (Bogataj 2012); Bogataj and Krč (2014) call it "state ignorance«. Namely, the Constitution of the Republic of Slovenia (1991) (hereinafter: Constitution) only recognises public good and private property. Nowadays, the role of common good in promoting interconnectivity and landscape conservation is brought to the fore (Rodela 2012b). The absence of management or even the "sale " of common land can lead to land use changes and, as a consequence, to landscape changes that can particularly affect the citizens without land. They are powerless and without real influence, and thus lose various rights that are otherwise taken for granted.

It is still unclear - among experts and even more among the general public - as to what constitutes common good and public good, what lies in the public interest, what the substantial differences are among them, and how these differences are reflected in the landscape, or in our relationship to it. Therefore, the relationships between state and local communities, the owners, and other citizens also remain unclear.

The main purpose of this paper is to review the literature and national documents, and, through this, define the meaning and roles of various types of good in the rural cultural landscape. In this respect, we are particularly interested in the concept of the cultural landscape in light of common good, and the notions of common good and general interest in Slovenian legislation.

\section{Methods}

This paper employs integrative reviews, as our ambition is to provide the broadest overview of literature in order to more fully understand the phenomenon of concern. We combine data from the theoretical as well as empirical literature. In addition, state documents are also incorporated.

The paper is based on the analysis of various texts. We were focused on the collection of materials whose topic was the cultural landscape in the context of public/common good, and the literature on various types of good. We also included some national documents formalizing or defining public/common good. The main search terms were public good, common good, and public interest. Although there is a clear difference between the concept of common good and common property regime, in Slovenia common land is the very important part of common good. Thus we expanded our search terms to common land, agricultural communities, and pasture communities. The main databases were commonly known and open, such as Google Scholar, JSTOR, and Scopus. 


\section{Cultural landscape}

In the literature the concept of cultural landscape is one of the most widely used, though it is, despite its wide range as to its use and content - or precisely because of this - burdened or benefited by a variety of conceptual starting points. Ever since Carl Sauer, who in 1925 introduced the term cultural landscape (according to the author, a cultural landscape is fashioned from a natural landscape by a cultural group as a medium for its activities; Sauer 1963, 343), the term has been continuously upgraded in terms of meaning and range, and later also acquired cognitive and experiential dimensions (Cosgrove 2008). The landscape is both a tangible and intangible (mental, imaginative) concept, formed through perception, imagination, and representation. Interaction between humans and the material part of the landscape generated a variety of intangible elements, such as myths, stories, values, tradition, creativity, and similar, which affected our understanding of the landscape as the aesthetic, heritage, and identity good of an individual, group, or nation (Urbanc 2011).

The understanding of the cultural landscape as a good opened a new dimension in the light of ecosystem services (hereinafter: ESs). ESs are the benefits the human society obtains from nature, while the term was first used by Ehrlich and Ehrlich in 1981 (after Fisher, Turner and Morling 2009). Nevertheless, despite the increasing number of studies we still lack a single definition of ESs. Landscape elements and the processes therein allow for and support certain functions that generate various services for man. The most widely used is the following differentiation between four types of ESs: supporting, provisioning, regulating, and cultural services (Millennium Ecosystem Assessment 2005). While supporting and regulating ESs provide processes related to ecosystems' long-term functionality and self-preservation capacity, provisioning services are services that are directly beneficial to humans (such as food, drinking water, fuelwood); cultural services relate to connecting nature and man. In terms of providing various goods and ESs needed for human wellbeing, it is crucial to have a diverse range of landscape elements that largely depend on human life and activities in an environment. They are significantly influenced by various cultural practices and traditional knowledge, through which a close connection between tangible and intangible aspects of the cultural landscape is established (Šmid Hribar 2014).

Farmers are the most important stakeholders and shapers in the rural landscape, which will be the focus in the continuation of this paper. In general, changing farming practises alter the landscape, as reflected in its appearance, biodiversity, cultural heritage, recreational opportunities, and other functions, which the residents understand and take for granted. The landscape provides the mentioned goods mostly through cultural ESs, which are, unlike the other three types of services, rarely the study subject, and even then their meaning is frequently reduced to recreational and tourist aspects, while their significance in the conservation of heritage, identity, as well as spiritual, inspirational, aesthetic, and educational values are neglected. It is precisely these cultural services that are important for local residents because, unlike tourists/visitors, they need and use them daily, and they are most affected by their change or loss.

Normative documents understand the landscape in a fairly traditional/material sense. Article 3 of the Cultural Heritage Protection Act (2008) defines the cultural landscape as: »... open space with natural and man-made elements whose structure, development, and use are mostly determined by human interventions and activities." At the European level, the European Landscape Convention (2001, Article 1) particularly contributed to the cultural landscape's recognisability, particularly the role of subjective perception of it; according to the Convention »landscape means an area, as perceived by people, whose character is the result of the action and interaction of natural and/or human factors. "The Florence Declaration on Landscape (2012) underlines the fact that considering that the landscape is a common good, the right to the landscape is a human necessity. 


\section{The concept of good}

Thinking about the roles and forms of goods in the landscape is inextricably linked to understanding its content, structure, and manifestations. The Standard Slovene Dictionary (Slovar ... 2015) defines good as that which is »intended for meeting human needs", where goods can be economic, consumable, material, spiritual, cultural, etc. In this dictionary, which is not normative but merely informative, we learn that a second meaning is "benefit, and a good, positive feature».

Samuelson (1954, after Ostrom 2009) distinguished between private versus public goods, and defined the former as excludable and rival, while the latter are non-rival and non-excludable. Similarly, Musgrave (1969, after Desmarais-Tremblay 2013) confirmed that the two criteria (excludability and rivalry) play different roles, and do not overlap. The discussion about the accessibility triggered questions on other types of good where there is a single criterion, such as a good whose consumption leads to no subtractions (non-rival), but is not accessible by everyone (excludable) (Buchanan 1965, after Desmarais-Tremblay 2013). By combining the criteria of (non)excludability and (non)rivalry, Musgrave and Musgrave (1973) used a theoretical model to identify four types of good (Figure 1 left). A few years later, Ostrom and Ostrom (1977, after Desmarais-Tremblay 2013) were the first to publish a table showing concrete examples of various types of good (Figure 1 right), where the criterion of rivalry of consumption was replaced by the criterion of subtractability of use showing the degree of the good left after its use (Ostrom 2009). Besides, in their concept Ostrom and Ostrom did not characterise the individual criteria as either fully present or absent, i.e. excludable versus non-excludable, or rival versus non-rival, but they recognised that there are intermediate stages among the systematised categories.

The four types of good are: private good, common good, club/toll good, and public good. The basic types of good are further divided into several subtypes according to the changing of attributes. In this paper we are particularly interested in public good and common good, and their manifestations in the landscape.

Public good is available to everyone and is non-subtractable, e.g. toll-free roads, peace, national security, protection against UV radiation, and similar (Ostrom and Ostrom 1977). The provision of a public good where the market mechanism fails is based on an efficient tax policy. In this respect, the researches soon realized that the number of users plays an important role - from both taxpayers and the users of the good (Buchanan 1965, after Desmarais-Tremblay 2013; Musgrave 1969, after Desmarais-Tremblay 2013).

Common good is again available to everyone, but subtractable, so it is necessary to have rules regulating the number of users, and the manner and range of use. Common-pool resources are a type of common good that the survival of a community depends on. If a farmer brought a hundred cows to graze on a shared

\begin{tabular}{|c|c|c|c|c|c|c|}
\hline & & & \multirow{6}{*}{  } & & \multicolumn{2}{|c|}{ EXCLUSION } \\
\hline & & & & & Easy & Difficult \\
\hline & EXC & USION & & High & $\begin{array}{l}\text { Private goods } \\
\text { (e.g. doughnuts, }\end{array}$ & $\begin{array}{l}\text { Common-pool Resources } \\
\text { (e.g. irrigation systems, }\end{array}$ \\
\hline CONSUMPTION & Feasible & Not Feasible & & Low & \multirow{3}{*}{$\begin{array}{l}\text { Club goods } \\
\text { (e.g. day-care centers, } \\
\text { country clubs) }\end{array}$} & \multirow{3}{*}{$\begin{array}{l}\text { Public goods } \\
\text { (e.g. sunset, } \\
\text { common knowledge) }\end{array}$} \\
\hline Rival & 1 & 2 & & & & \\
\hline Non rival & 3 & 4 & & & & \\
\hline
\end{tabular}

Figure 1: Four types of good: left - Musgrave's mathematical model of types of good (Musgrave and Musgrave 1973, after Desmarais-Tremblay 2013), right - a table with examples of goods (adapted from Hess and Ostrom 2003). 
pasture, there would be no pasture left for the grazing of other farmers' cattle. Based on many case studies, Ostrom, Gardner, and Walker (1994, after Ostrom 2005) found that the users in self-organised systems develop a series of rules on the use of resources, control of use, and sanctions for offenders. The practices of managing common good are at the heart of the sustainability concept preventing the »tragedy of the commons (Hardin 1968). The key element is the right to property, which must be understood in a broad sense, not only from the aspect of the right to sell (Ostrom 2009). Ostrom (2009, 419-420) exposed the following types of property rights: (1) access - the right to enter a specified property, (2) withdrawal - the right to harvest specific products from a resource, (3) management - the right to transform the resource and regulate internal use patterns, (4) exclusion - the right to decide who will have access, withdrawal, or management rights, and (5) alienation - the right to lease or sell any of the other four rights.

As to the traditional types of common good, Olwig (2013) places particular emphasis on the necessity of the interaction between material commons and cultural commons, i.e. what constitutes a community. The traditional common good together with traditional knowledge and governance practices in the globalisation age are increasingly at risk, while, on the other hand, new types of common good emerge, and, indeed, in very different forms, both material and immaterial.

The concept of good was later used and modified by many authors. One of the modifications for classifying ES as a support in decision-making was used by Fischer, Turner and Morling (2009), who underlined the fact that some ecosystem benefits, which are non-rival with low consumption, become more rival with increased consumption (Figure 2). They also pointed out to the potential gap between the areas where ES are created, and the areas where they are used.

From a management perspective, Duraippah et al. $(2014,95)$ found that until now primarily provisioning services were studied, while the roles of processes and ecosystem functions were neglected. They pointed out that provisioning ES are characterised by subtractability, while regulating ESs are non-excludable and non-rival, thus exhibiting the characteristics of public good. They expose the concept of the new commons, which is not fixed, but adaptable, and defined as: "a spatial mosaic involving land, water, climate, and their underlying levels of biodiversity, ecological functions and processes that support and provide the bundles of regulating services, and that maintain a sustainable supply of provisioning common pool resources for human well-being."

Common good also includes electricity generated from renewable natural resources. Electricity, or rather the lack of it, was what brought together the residents of the Scottish Isle of Eigg. Unreliable electricity supply and the absentee ownership that made effective managing of natural resources impossible led to the residents' initiative to buy the island. The island was bought by the Isle of Eigg Heritage Trust, consisting of the residents of Eigg, the Highland Council, and the Scottish Wildlife Trust (Internet 1). They built a self-sufficient system of power generation, using hydro, wind and solar energy, which was successfully connected into its own grid (Internet 2).

\begin{tabular}{|c|c|c|c|c|}
\hline \multirow{4}{*}{ Rival } & \multicolumn{3}{|l|}{ Excludable } & Non-Excludable \\
\hline & private good & & & open access \\
\hline & ecosys. service benefit & \multicolumn{2}{|c|}{ high use } & \multirow{2}{*}{ some fisheries } \\
\hline & e.g. almonds & $\uparrow$ & $\uparrow$ & \\
\hline \multirow{2}{*}{ Non-Rival } & tool/club good & $\begin{array}{l}\text { insore } \\
\text { fishery }\end{array}$ & $\begin{array}{c}\mathrm{CO}_{2} \\
\text { storage }\end{array}$ & pure public good \\
\hline & information from nature & \multicolumn{2}{|c|}{ low use } & UV protection \\
\hline
\end{tabular}

Figure 2: Illustration of ES and benefits from the aspect of (non)rivalry and (non)excludability in their consumption (after: Costanza 2008; Fisher, Turner and Morling 2009). 


\subsection{Common good and common land in Slovenia}

Slovenia has a rich tradition of common good in the form of common land dating far back to the period of tribal communities. Vilfan $(1996,237)$ reports various cases of common land, which were called komunšna, and also komunela in West Slovenia, while the Slovene term gmajna (i.e. the village commons) was derived from the German die Gemein. This was usually uncultivated land intended for grazing, and common forests where wood could be harvested for personal use. By the end of Feudalism, the rights to common land were more or less uniform and depended on a person's affiliation with a local community, but afterwards these rights started to differentiate. Vilfan $(1996,265)$ underlines the fact that the remains of the former village community were "preserved in those legal institutions of the village autonomy where collective management was exercised «. It is also noteworthy that the General Civil Code (German: Allgemeines bürgerliches Gesetzbuch) of the Habsburg Monarchy, which entered into force on 1 January 1812, distinguished between (a) public good, which covered things available to all citizens (e.g. public roads, watering places), (b) municipal good, which was benefited by the residents, and (c) municipal property, from which municipal costs were covered (Vilfan 1996). However, Vilfan points out the difficulty of classifying the various types of common property according to these legal categories. The right to common or municipal good differed from one place to another. For example, gmajna was registered in the Land Register in the form of co-ownership shares (the same or different ones), or as the property of the "neighbourhood «, i.e. the local community. In the latter case, the neighbourhood kept a more significant impact on managing common good, where certain rules were applied as to the nature of the circle of beneficiaries, and the conditions for accepting new members, if any. Overall, this resulted in well diversified forms of managing common good.

The so-called agricultural communities (hereinafter: ACs) managed the common property; they were also called sose(d)ska, srenja, jus, sopašnik, or skupnina (Bogataj 2012). ACs are in charge of common management of agricultural and forest land (pastures, forests, fallow land, ponds), particularly in hilly areas which remained undivided after the completion of the agrarian reform in 1848 (Petek and Urbanc 2007). This land usually had less favourable natural conditions (Hrvatin and Perko 2008), and was therefore less arable. ACs were abolished in 1947 and 1965, respectively, and the property was nationalised (Agrarian Communities Act 1947; Disposal of the Property ... 1965). Approx. 1000 ACs, and unofficially as much as 1500, were abolished (Cerar, Kliner and Papež 2011), while the land area size is unknown. The Denationalization Act of 1991 enabled the restitution of agricultural and forest land to their owners and was the basis of the Act on Reestablishment of Agricultural Communities and Restitution of their Property and Rights (1994), which returned property to the former AC members as their joint ownership or common property. Premrl (2013) reports that 638 ACs are registered in the Administrative Unit Registers, of which 547 are potentially active, while the procedures regarding property restitution have not been completed for $48 \mathrm{ACs}$. $77,486.47$ ha of land was returned to ACs, which is $3.67 \%$ of the territory of Slovenia (Premrl 2013).

Nowadays, to maximise revenues, the former agricultural and forestry practices are transitioning into using renewable energy resources, such as wind and sun (Premrl and Krč 2012). To this Bogataj $(2012,24)$ adds the community's interest for "production of wood, for mowing (because of subsidies), for many »attractive land plots", airports, rational forest management, recreation, and nature protection«.

\section{Overview of terminology in the Slovenian legislation}

\subsection{Common good}

The notion of »common good «(Slovene: skupno dobro), is not specifically defined in the Slovenian legislation. The term was already used in religious texts in the translations of Thomas Aquinas in the $13^{\text {th }}$ 
Century. Aquinas says that the good or common wellbeing must be taken into account in the legislation, because laws should be »directed towards the common happiness and prosperity (Žalec 2014). In Scotland, the Common Good Act was passed in 1491. The term does not occur in Slovenian legislation; in fact, it is only used in a few documents adopted at the European level, but there it is not clearly defined. The Resolution of the Council of the European Union of 1997 on common European environmental legislation (Council resolution ... 1997) says that "the environment is a common good frequently not linked to a private interest .

\subsection{Public good}

In 1991, after a break of several decades, the Constitution reintroduced the term "public good « into the Slovenian legislation. Nevertheless, it was always present in legal theory and the literature dealing with land use, but with terms such as: goods in general use, social ownership in general use, etc. The meaning of public good must be clearly defined, instead of it being used inconsistently and unsystematically (Vugrin 2005). It is inherent in Article 70 of the Constitution (2006) in the context of using natural resources. Also, the Constitution provides for the right to private property (Article 33), which is, however, not absolute - Article 67 of the Constitution stipulates that the manner in which property is acquired and enjoyed shall be established by law so as to ensure its economic, social, and environmental function. Various laws define »public good « in a range of fields. In the sense of landscapes, the following laws are particularly important in Slovenia (Vugrin 2005):

- Public good is defined in Article 19 of the Law of Property Code (2002) as a matter in general use; according to its purpose it can be used by anybody under the same conditions.

- The Waters Act (2002) defines the natural and built public assets of national (e.g. motorways, railway) and local significance (squares, streets, playgrounds, etc.). Natural public water assets are inland waters and water land, as well as the sea and marine water land.

- The Construction Act (2002) defines built public good, i.e. land intended for such general use as stipulated by law regarding the purpose of its use, or regulation issued based on the law and the structures built on it, if they are intended for general use.

- The Public Roads Act of 1997 defines public roads as public good, while they cannot be the object of legal transactions.

- The Environmental Protection Act (2006, Article 3) defines the term public natural assets in the Definitions related to natural goods. A natural asset is a component of the environment designated by law as a public asset; it can only be used in a way which is not detrimental to the environment or one of its parts that has the status of a public natural asset, where the existence of its natural role is not excluded. It is manifested as public natural assets, natural resources, or natural values.

- The Cultural Heritage Protection Act (2008) does not mention public good, but it does mention public benefit. Cultural heritage protection is defined as a public benefit, which means identifying heritage, its values, safeguarding, conservation, education, and training.

The notion of "public good " (Slovene: javno dobro) is inconsistently translated into English as national asset (frequently) and public/national good (less frequently).

\subsection{Public interest}

Of the three terms used in Slovenian legislation, public interest is probably the most inconsistently used. Besides "public interest «, "public benefit " (Mining Act 2014; Nature Conservation Act 2004; Cultural Heritage Protection Act 2008), and "general interest « also come up. The most direct definition is found in the Public-Private Partnership Act (2006): "»public interest « is a general benefit, as defined by an act or regulation issued on the basis thereof «. Public interest is general interest as defined by national legislation, which also lays down the values pursued by public interest. The Spatial Planning Act (2007, 
Article 7) contains the most unambiguous definition of public interest and the relationship between public and private interest - saying that, in spatial planning, private interest must not harm public interest.

In most legislative cases the term is used to define the status of various legal entities, bestowing upon such organisations "status of acting in the public interest «. Slovenian legislation regulates the acquisition of this status for 29 different fields (culture, sports, social security, etc.) if it is found that their activities transcend the private interests of their founders or members, i.e. that they act in public interest (Societies Act 2006).

\section{Discussion}

In the cultural landscape public and common goods are particularly interesting due to their benefits to the general public. Accessibility is a shared feature, but they differ in use - while common good is subtractable, public good is not. Common good also includes common resources and common land. Nevertheless, common land in Slovenia is in decline, as a consequence of (1) the abolition of ACs and nationalised property under Yugoslavia, and (2) inappropriate legislation on denationalising common land in the independent Slovenia. At the same time, at home and abroad there are tendencies toward new forms of common good, relating mostly to the use of renewable resources (wind, sun, wood), as demonstrated by the case of the Isle of Eigg's energy self-sufficiency, and the desire for a similar kind of management in some ACs in the Slovenian Karst region, as reported by Premrl and Krč (2012).

We find that in Slovenian legislation the terms common and public good are not systematically defined, i.e. with clearly distinguishable meanings; moreover, the existing Constitution does not include the term of common good, even though in the past this special category was already recognised in Slovenia. This leads to inconsistent use of these terms. The terms are differently used, both semantically and terminologically, in sectoral legislation concerning the individual cultural landscape elements good (e.g. water, cultural heritage). This creates additional risks to common and public good, particularly in Central Eastern European countries, under the conditions of neoliberal and neo-corporative economies, which are under the pressure of privatisation and transformations from collectively- to privately-owned property (Bohle and Greskovits 2007).

Common land and ACs were strongly affected by the Agrarian Communities Act of 1947, which prohibited them, and the Disposal of the Property of Former Agrarian Communities Act of 1965, which nationalised common land and declared it as "general property«. Paradoxically, additional problems were caused by denationalisation, because under the Denationalization Act of 1991 land was returned to its individual heirs, not to the former ACs. Ownership was (possibly) transferred to heirs who did not engage in agriculture and did not share common interests with ACs. Individualisation can lead to privatisation of once-common land, and possibly results in the change of land use: intensification, abandonment, or change of purpose. The Act on Reestablishment of Agricultural Communities (1994) took into account specific details of common land ownership, but it does not act in retrograde for the procedures started under the first act. To this date, the judicial proceedings of many ACs are still in process. This confirms the hypothesis that the existence and manifestation of the common good are reflections of the economic and political situation.

Neglect at the institutional level puts common good at risk. We agree with Bogataj $(2012,33)$ who warns that common property as a special category of property should again be recognised to "acknowledge tradition and practices, to make it consistent with the rest of the world, and recognise that ACs also provide public benefits«. In some European countries, private, public, and common good were delineated several centuries ago - in Scotland as early as 1491 - thus delimiting the relationship between private and common land. Due to the aforementioned political reasons, such an understanding was no longer in place in Slovenia, therefore it is nowadays very important to clearly define common good 
in the basic documents (Constitution, Law of Property Code), and subsequently transfer it - uniformly into sectoral legislation.

Socio-political processes affected the changing of the cultural landscape and the various manifestations of good therein, and, as a result, the functions of the landscape and its ESs. By changing the ownership, particularly by transforming the land in common property into land in private property, the control over landscape and its ESs changes as well. The relationships and expectations concerning managing common good are changing as justified by Premrl et al. (2015). Finally, our way of life changes, as mostly demonstrated by the phenomenon of individualisation in our society. This leads to the abandonment of land use or overgrowth, resulting in the loss of footpaths, which are a public good. Such changes bring new land uses and also alter the cultural landscape, as well as existing services and goods offered to the residents. Contemporary residential neighbourhoods, for example, have less common spaces than older neighbourhoods. Figure 3 shows various types of goods manifested in the landscape. Similarly to Fisher, Turner and Morling (2009), we feel that an important factor in landscape management is the knowledge of whether the landscape goods and services are subtractable or not. This is the point where conflicts between various stakeholders often occur, i.e. due to their different interests in the same landscape; therefore, the cultural landscape must be governed. In recent years, the landscape has seen many conflicts when meeting the needs of various stakeholders, where, on the one hand, agriculture is increasingly intensified in the desire to maximize food production, and, on the other hand, the expectations and needs for environmental and cultural services are greater. History, and the governance case of the Isle of Eigg, teach us how communities can actively influence and control the landscape they live in. This is confirmed by the results of Elinor Ostrom, who won the Nobel Prize for her conclusion that people - when facing a limited resource - are able to act and collaborate for the benefit of common good (Anderies and Janssen 2013). One of the important characteristics of common management is that when managing common resources community members have rights as well as obligations or responsibilities, which are counterbalanced (Bogataj 2012; Anko 2013).

Another conclusion, based on Figure 3, is that in the landscape some types of public good (e.g. air, flood protection), unlike roads and paths, in fact depend on other types of good (e.g. meadows, forests, as types of private/common good). Here we refer to the public good in the form of supporting, regulating,

\begin{tabular}{|c|c|c|c|}
\hline & & \multicolumn{2}{|c|}{ EXCLUSION } \\
\hline & & EASY & DIFFICULT \\
\hline $\begin{array}{l}\text { S } \\
\text { U } \\
\text { B } \\
\text { T } \\
\text { R } \\
\text { A }\end{array}$ & $\begin{array}{c}\mathbf{H} \\
\mathbf{I} \\
\mathbf{G} \\
\mathbf{H}\end{array}$ & $\begin{array}{l}\text { private goods } \\
\text { benefits for landowners } \\
\text { - landscape elements with agricultural and forest land use } \\
\text { (e. g. arable land, meadows, forests) } \\
\text { - buildings } \\
\text { - provisioning ecosystem services }\end{array}$ & $\begin{array}{l}\text { common goods } \\
\text { benefits for the community with land use rights } \\
\text { - common land (mostly pastures and less valuable forests) } \\
\text { with open access } \\
\text { - drinking water supplies } \\
\text { - fruits in an open access city orchard }\end{array}$ \\
\hline $\begin{array}{l}\text { T } \\
\text { A } \\
\text { B } \\
\text { I } \\
\text { L } \\
\text { I } \\
\text { T } \\
\text { Y }\end{array}$ & $\begin{array}{l}\mathbf{L} \\
\mathbf{O} \\
\mathbf{W}\end{array}$ & $\begin{array}{l}\text { club/toll goods } \\
\text { benefits for the users willing to pay } \\
\text { - protected areas with entrance fees } \\
\text { - river canoeing with rent/permit fees }\end{array}$ & $\begin{array}{l}\text { public goods } \\
\text { benefits for the general public } \\
\text { - paths, roads, open public spaces, e. g. squares } \\
\text { - flood protection, protection against UV radiation } \\
\text { - protected areas with no entrance fees } \\
\text { - built public good (e.g. schools) } \\
\text { - supporting, regulating, and cultural ecosystem services } \\
\text { - open space and greenery in a city (e.g. city orchard as } \\
\text { a public green space) }\end{array}$ \\
\hline
\end{tabular}

Figure 3: The quadrant with various types of good in the cultural landscape. 
and cultural ESs, which are not subtractable, but are inextricably linked with landscape elements, which are most often private good, whose use is intensified. While common land with open access still importantly contributes to public and common goods, private land use is frequently directed at providing provisioning ESs which are subtractable. We must keep this in mind in the future as, indeed, the provision of various, particularly cultural ESs, such as the possibility of recreation, aesthetic, and spiritual experience of the landscape, identity preservation, and similar, cannot be taken for granted.

\section{Conclusions}

In this paper, our aim was to define the role of different types of good in the cultural landscape. Based on the review of the literature, in broad terms we distinguish between private, club/toll, common, and public good. The private and club/toll good are characterised by the excludable access, unlike public and common goods. The main difference between common and public good is in their use unlike public good, common good is subtractable, so it should be managed. It is an entirely different situation with supporting, regulating, and cultural ESs, which are neither subtractable nor excludable, which places them in the category of public good. However, these types of good are not necessarily institutionalized. For example, the Constitution does not include the notions of common good and common property, even though in the past this special ownership category was recognised and it is manifested in the landscape mostly as common land. The legal and formal unfamiliarity of common good puts at risk the existence of the already reduced areas of common land, leading to the changing of the landscape, its functions, and ESs. This affects, among others, the reduction of public benefits, such as the provision of recreation, conservation of heritage, identity, spiritual, inspirational, aesthetic, and educational values.

\section{References}

Act on Reestablishment of Agricultural Communities and Restitution of their Property and Rights (Zakon o ponovni vzpostavitvi agrarnih skupnosti ter vrnitvi njihovega premoženja in pravic). Uradni list Republike Slovenije 5/1994. Ljubljana.

Agrarian Communities Act (Zakon o agrarnih skupnostih). Uradni list Socialistične republike Slovenije 52/1947. Ljubljana.

Anderies, J. M., Janssen, M. A. 2012: Sustaining the Commons. Tempe. Internet: http://sustainingthecommons.asu.edu/wp-content/uploads/2013/07/Sustaining-the-Commons-v101.pdf (1.6.2015).

Anko, B. 2013: Pogledi na trajnost danes. Znamenja trajnosti. Ljubljana. Internet: http://arhiv.acs.si/ publikacije/Znamenja_trajnosti_ACS_mini_za_objavo_na_www.pdf (10.2.2015).

Bogataj, N. 2012: Model delovanja slovenskih agrarnih skupnosti. Soupravljanje naravnih virov: vaške skupnosti in sorodne oblike skupne lastnine in skupnega upravljanja. Wageningen.

Bogataj, N., Krč, J. 2014: A forest commons revival in Slovenia. Society and Natural Resource 27-8. London. DOI: http://dx.doi.org/10.1080/08941920.2014.918225

Bohle, D., Greskovits, B. 2007: Neoliberalism, embedded neoliberalism and neocorporatism: Towards transnational capitalism in Central-Eastern Europe. West European Politics 30-3. Oxford. DOI: http://dx.doi.org/10.1080/0140238070127628

Britovšek, M. 1964: Razkroj fevdalne agrarne strukture na Kranjskem. Razprave in eseji 5. Ljubljana.

Buchanan, J. M. 1965: An economic theory of clubs. Economica 32-125.

Buchecker, M., Hunziker, M., Kienast, F. 2003: Participatory landscape development: overcoming social barriers to public involvement. Landscape and Urban Planning 64, 1-2. Amsterdam. DOI: http://dx.doi.org/10.1016/S0169-2046(02)00199-8 
Cerar, G., Kliner, P., Papež, M. 2011: Prihodnost agrarnih skupnosti. Zelena dežela 102. Ljubljana. Internet: http://www.kgzs.si/Portals/0/Dokumenti/glasilo/ZD102_w.pdf (15.11.2012).

Constitution of the Republic of Slovenia (Ustava Republike Slovenije). Uradni list Republike Slovenije 33/1991-I, 42/1997, 66/2000, 24/2003 in 69/2004 68/2006. Ljubljana.

Construction Act (Zakon o graditvi objektov). Uradni list Republike Slovenije 110/2002. Ljubljana.

Cosgrove, D. 2008: Social Formation and Symbolic Landscape. London.

Costanza, R. 2008: Ecosystem services: Multiple classification systems are needed. Biological Conservation 141-2. Barking. DOI: http://dx.doi.org/10.1016/j.biocon.2007.12.020

Council resolution of 7 October 1997 on environmental agreements. Official Journal C 321 (97/C 321/01). Brussels.

Cultural Heritage Protection Act (Zakon o varstvu kulturne dediščine). Uradni list Republike Slovenije 16/2008, 123/2008, 8/2011. Ljubljana.

Denationalization Act (Zakon o denacionalizaciji). Uradni list Republike Slovenije 27I/1991-I. Ljubljana.

Desmarais-Tremblay, M. 2013: On the definition of Public Goods. Assessing Richard A. Musgrave's contribution. Internet: ftp://193.55.96.54/pub/mse/CES2014/14004.pdf (10.3. 2015).

Disposal of the Property of Former Agrarian Communities Act (Zakon o razpolaganju s premoženjem bivših agrarnih skupnosti). Uradni list Republike Slovenije 7/1965. Ljubljana.

Duraippah, A. K., Asah, S. T., Brondizio, E. S., Kosoy, N., O'Farrell, P. J., Prieur-Richard, A., Subramanian, S. M., Takeuchi, K. 2014: Managing the mismatches to provide ecosystem services for human well-being: a conceptual framework for understanding the New Commons. Current Opinion in Environmental Sustainability 7. Amsterdam. DOI: http://dx.doi.org/10.1016/j.cosust.2013.11.031

Environmental Protection Act (Zakon o varstvu okolja). Uradni list Republike Slovenije 39/2006. Ljubljana.

European Landscape Convention. Internet: http://www.coe.int/t/dg4/cultureheritage/heritage/Landscape/ Publications/Convention-Txt-Ref_en.pdf (16.6.2015).

Fisher, B., Turner, R. K., Morling, P. 2009: Defining and classifying ecosystem services for decision making. Ecological Economics 68-3. Amsterdam. DOI: http://dx.doi.org/10.1016/j.ecolecon.2008.09.014

Florence Declaration on Landscape, 2012. Internet: http://whc.unesco.org/en/news/943/ (16. 6. 2015)

Gatto, P., Bogataj, N. 2015: Disturbances, robustness and adaptation in forest commons: Comparative insights from two cases in the Southeastern Alps. Forest Policy and Economics 58. Amsterdam. DOI: http://dx.doi.org/10.1016/j.forpol.2015.03.011

Gatto, P., Secco, L., Florian D., Petenella, D. 2011: Sustainable local governance and forest management: The new challenges for Forest Common Properties in the Veneto Region (Italian Eastern Alps). International Workshop Forest Commons-Role Model for sustainable local governance and forest management. Burbach.

Hardin, G. 1968: The tragedy of the commons. Science 162-3859. DOI: http://dx.doi.org/10.1126/ science.162.3859.1243

Ostrom, E., Gardner, R., Walker, J. 1994: Rules, Games and Common-Pool Resources. Ann Arbor.

Hess, C., Ostrom, E. 2003: Ideas, Artifacts, and Facilities: Information as a Common-Pool Resource. Law and Contemporary Problems 66. Durham.

Hrvatin, M., Perko, D. 2008: Landscape characteristics of common land in Slovenia. Acta geografica Slovenica, 48-1. DOI: http://dx.doi.org/10.3986/AGS48101

Internet 1: http://news.bbc.co.uk/2/hi/uk_news/magazine/7220610.stm (18.6. 2015).

Internet 2: http://www.isleofeigg.net/eigg_electric.html (18.6.2015).

Jenko, M. 2012: To, kar so naredili Ekologi brez meja, je fenomenalno. Delo, Sobotna priloga, (3. marec 2012), 54-52. Ljubljana. Internet: http://www.delo.si/zgodbe/sobotnapriloga/nives-dolsak-kar-sonaredili-ekologi-brez-meja-je-fenomenalno.html (16.6.2015).

Johann, E. 2013: The history of utilization and management of commons and consequences of current social change in the Alpine Region of Austria. Cultural Severance and the Environment. Dordrecht. Law of Property Code (Stvarnopravni zakonik). Uradni list Republike Slovenije 87/2002. Ljubljana. 
Millennium Ecosystem Assessment (MA) 2005: Ecosystems and Human Well-being: synthesis. Washington. Internet: http://www.millenniumassessment.org/documents/document.356.aspx.pdf (30. 10.2013).

Mining Act (Zakon o rudarstvu). Uradni list Republike Slovenije 14/2014. Ljubljana.

Musgrave, R. A. 1969: Provision for social goods. Public Economics: An analysis of Public Production and Consumption and their Relations to the Private Sectors. London.

Musgrave, R. A., Musgrave, P. 1973: Public Finance in Theory and Practice. New York

Nature Conservation Act (Zakon o ohranjanju narave). Uradni list Republike Slovenije 96/2004. Ljubljana.

Olwig, K. R. 2013: Globalism and the enclosure of the landscape commons. Cultural Severance and the Environment. Dordrecht.

Ostrom, E. 2005: Understanding Institutional Diversity. Internet: http://press.princeton.edu/chapters/ s8085.pdf (15.4.2015).

Ostrom, E. 2009: Beyond Markets and States: Polycentric Governance of Complex Economic Systems. Internet: http://www.nobelprize.org/nobel_prizes/economic-sciences/laureates/2009/ostrom_lecture.pdf (18.6.2015).

Ostrom, V., Ostrom, E. 1977: Public goods and public choices: The emergence of public economies and industry structures. Alternatives for Delivering Public Services: Toward Improved Performance.

Petek, F., Urbanc, M. 2007: Skupna zemljišča v Sloveniji. Geografski vestnik 79-2. Ljubljana.

Premrl, T. 2013. Analiza stanja agrarnih skupnosti v Sloveniji na podlagi podatkov upravnih enot. Elaborat, Gozdarski inštitut Slovenije. Ljubljana.

Premrl, T., Krč, J. 2012: Kraške agrarne skupnosti: primer upravljanja naravnih virov v agrarnih skupnosti Gabrče in Križ Filipčje Brdo. Soupravljanje naravnih virov: vaške skupnosti in sorodne oblike skupne lastnine in skupnega upravljanja. Wageningen.

Premrl, T., Udovč A., Bogataj, N., Krč, J. 2015: From restitution to revival: A case of commons re-establishment and restitution in Slovenia. Forest Policy and Economics 59. Amsterdam. DOI: http://dx.doi.org/ 10.1016/j.forpol.2015.05.004

Public-Private Partnership Act (Zakon o javno-zasebnem partnerstvu). Uradni list Republike Slovenije 127/2006. Ljubljana.

Public Roads Act (Zakon o javnih cestah). Uradni list Republike Slovenije 29/1997, 33/2006, 45/2008, 42/2009, 109/2009. Ljubljana.

Rodela, R. 2012a: Uvod v skupno lastnino in skupno upravljanje naravnih virov. Soupravljanje naravnih virov: vaške skupnosti in sorodne oblike skupne lastnine in skupnega upravljanja. Wageningen.

Rodela, R. 2012b: Dva primera iz prakse v Tržaški pokrajini: jusarska skupnost Opčine in srenjska skupnost Boljunec. Soupravljanje naravnih virov: vaške skupnosti in sorodne oblike skupne lastnine in skupnega upravljanja. Wageningen.

Samuelson, P. A. 1954: The pure theory of public expenditure. The Review of Economics and Statistics 36-4. Cambridge.

Sauer, C. 1963: Land and Life: A Selection from the Writings of Carl Ortwin Sauer. Berkeley.

Slovar Slovenskega knjižnega jezika (elektronska izdaja). Ljubljana, 2015.

Societies Act (Zakon o društvih). Uradni list Republike Slovenije 61/2006, 58/2009, 39/2011. Ljubljana.

Spatial Planning Act (Zakon o prostorskem načrtovanju). Uradni list Republike Slovenije 33/2007. Ljubljana.

Šmid Hribar, M. 2014: Trajnostno varovanje in usmerjanje razvoja kulturne pokrajine na izbranem območju Krajinskega parka Ljubljansko barje. Doktorsko delo, Fakulteta za humanistične študije Univerze na Primorskem, Koper.

Terkenli, T. S. 2001: Towards a theory of the landscape: the Aegean landscape as a cultural image. Landscape and Urban Planning 57, 3-4. Amsterdam. DOI: http://dx.doi.org/10.1016/S0169-2046(01)00204-3 Urbanc, M. 2002: Kulturne pokrajine v Sloveniji. Geografija Slovenije 5. Ljubljana.

Urbanc, M. 2008: Večdimenzionalnost pokrajine: primer slovenske Istre. Geografski vestnik 80-2. Ljubljana. Urbanc, M. 2011: Pokrajinske predstave o slovenski Istri. Georitem 15. Ljubljana. 
Vilfan, S. 1957: Podobe iz nekdanje živinoreje med Trstom in Slavnikom. Kronika 5-2. Ljubljana.

Vilfan, S. 1972: Komun pri Črnotičah. Traditiones 1. Ljubljana.

Vilfan, S. 1996: Zgodovinska pravotvornost in Slovenci. Ljubljana.

Vugrin, M. 2005: Definiranje pojma javno dobro. Geodetski vestnik 49-3. Ljubljana.

Waters Act (Zakon o vodah). Uradni list Republike Slovenije 67/2002, 57/2008, 57/2012, 100/2013, 40/2014. Ljubljana.

Žalec, B. 2014: Dialoška mentaliteta kot pogoj vladavine prava. Vzgoja 16-62. Ljubljana.

\section{Povzetek: Javno in skupno dobro v kulturni pokrajini}

Glavni namen prispevka je pregled strokovne literature in državnih dokumentov ter opredelitev pomena in vloge različnih tipov dobrega v podeželski kulturni pokrajini. Še posebej nas zanimata koncept kulturne pokrajine v luči skupnega dobrega ter pojma skupno dobro in splošni interes v slovenski zakonodaji. Analiza temelji na pregledu slovenske in mednarodne literature ter slovenske zakonodaje.

Prepoznali smo štiri glavne kategorije: zasebno, plačljivo, skupno in javno dobro. V zvezi s skupnim dobrim, ki se nanaša na skupne vire, posebej izpostavljamo, da le-to ni enako skupni lastnini. V kategoriji skupnega dobrega izpostavljamo skupna zemljišča, ki so bila v preteklosti pomembna ekonomska dobrina, v sedanjem času pa postaja vse bolj pomembna njihova vloga pri zagotavljanju podpornih, uravnalnih in kulturnih ekosistemskih storitev. Vendar se obseg skupnega dobrega zaradi družbenoekonomskih razlogov zmanjšuje, poleg tega v slovenski zakonodaji ni bilo popolnoma jasno, $\mathrm{v}$ čem se skupno dobro razlikuje od javnega dobrega in kako se ti dve obliki kažeta $v$ današnji kulturni pokrajini oziroma v odnosu do nje. Ugotavljamo, da se delež skupnih dobrin, način njihove rabe in njihove koristi v kulturni pokrajini, ki jo zaznamuje odnos med naravnim okoljem in človeško družbo, spreminjajo skozi čas, nanje pa vplivajo tudi družbeno-politični procesi in formalno (ne)prepoznanje na institucionalni ravni. V Sloveniji so s skupno lastnino upravljale agrarne skupnosti, imenovane tudi sose(d)ska, srenja, jus, sopašnik in skupnina. Po letih 1947 in 1965 so bile agrarne skupnosti ukinjene in njihovo premoženje podržavljeno. V samostojni Sloveniji je bilo agrarnim skupnostim v okviru denacionalizacijskih postopkov do zdaj vrnjenih 77.486,47 hektarjev zemljišč, kar je 3,67 \% ozemlja Slovenije. V registrih upravnih enot je zavedenih 638 agrarnih skupnosti, od katerih jih je potencialno aktivnih 547.

Slovenska zakonodaja obravnava le pojma »javno dobro« in »skupni interes «, ne pa tudi pojma »skupno dobro«. Ustava Republike Slovenije pozna le javno dobro in zasebno lastnino. Javno dobro se pojavi v kontekstu izkoriščanja naravnih bogastev, a v sektorskih dokumentih, ki urejajo posamezne gradnike kulturne pokrajine, ni enotne in jasne definicije, ki bi urejala ali omogočala učinkovito upravljanje s skupnim dobrim.

Nadalje razpravljamo, kako javno in skupno dobro prinašata skupnosti koristi, pri čemer obstaja med njima pomembna pomenska razlika, saj skupno dobro $\mathrm{z}$ rabo upada. Zato zahteva premišljeno upravljanje ter ohranitev skupne lastnine, sicer skupnost izgubi nadzor nad zemljiščem. Za skupnosti in človeštvo nasploh postajajo vse pomembnejše podporne, uravnalne in kulturne ekosistemske storitve, ki sicer z rabo ne upadajo, a so neločljivo povezane s pokrajinskimi gradniki. Ti so največkrat $\mathrm{v}$ zasebni lasti, njihova raba pa je usmerjena v zagotavljanje oskrbovalnih ekosistemskih storitev, ki prinašajo koristi predvsem lastniku. To je točka, kjer v pokrajini pogosto prihaja do konfliktov med različnimi deležniki z lastnimi interesi. Tega se bo treba zavedati v prihodnje, saj zagotovitev različnih, še posebej kulturnih ekosistemskih storitev, kot na primer možnost rekreacije, estetskega in duhovnega doživljanja pokrajine, ohranjanje identitete ter podobno, ni samoumevno. Nedorečenost slovenske zakonodaje pri tem ni v pomoč, in to še dodatno ogroža obstoj skupnih zemljišč, ki so v postsocialističnih državah pod vplivi preobrazbe iz kolektivne v zasebno lastnino. Zato je v Sloveniji pomembno, da se v temeljnih dokumentih (Ustava, Stvarnopravni zakonik) jasno opredeli skupno dobro, ki se nato prenese na ostalo sektorsko zakonodajo. 
Izpostavljamo, da sta kategoriji zasebnega in plačljivega dobrega precej jasni - dostop do njiju je izključujoč, torej omejen. Pri skupnem in javnem dobrem pa je pomembnejša (po)raba: javno dobro se $\mathrm{z}$ rabo ne manjša (na primer zaščita pred UV-sevanjem je za vse enaka), medtem ko se skupno dobro $\mathrm{z}$ rabo manjša (na primer skupna zemljišča, zaloga pitne vode). Zato lahko sklenemo, da je s skupnim dobrim treba učinkoviteje upravljati in ga prepoznati tudi na zakonodajni ravni, še posebej če želimo krepiti in ohranjati kulturne ekosistemske storitve, kot so možnosti rekreacije, estetskega in duhovnega doživljanja pokrajine, ohranjanje identitete ter podobno. 